\title{
Die relevansie van die historiese Jesus- ondersoek vir kerklike teologie ${ }^{1}$
}

\author{
Andries van Aarde \\ Nuwe-Testamentiese Wetenskap \\ Fakulteit Teologie, Universiteit van Pretoria
}

\begin{abstract}
The relevance of historical Jesus research for the theology of the church

The aim of this article is to reflect on the implications of historical Jesus research for the theology of the church. It focuses on the relation between the pre-Easter Jesus and the post-Easter kerygmatic tradition. First, it discusses the reason why historical Jesus research is regarded as necessary. Second, a profile of Jesus is described. Third, the article demonstrates the discontinuity and material relation between Jesus' teaching and the theology of the church. It focuses on the kerygma that the death and resurrection of Jesus creates atonement.
\end{abstract}

\section{INLEIDING}

Die inhoud van hierdie voordrag moet gesien word as 'n terugskouing op my afgehandelde navorsingsprojek oor die historiese Jesus-vraagstuk en 'n vooruitskouing op my volgende projek oor die vroegste Jesus-beweging in Jerusalem. Die bedoeling van die voordrag is om te reflekteer oor die implikasies van aspekte van my historiese Jesusverstaan vir kerklike teologie. Ek fokus op die relasie tussen die voor-Pase Jesus en die na-pase kerugmatiese tradisie. Aspekte van hierdie sake het ek reeds in ander publikasies aangeraak of meer volledig bespreek. In die eerste plek verskaf ek kortliks die redes

\footnotetext{
1 Hierdie artikel word opgedra aan prof dr J H Koekemoer, emeritus-dekaan, Fakulteit Teologie (Afd A), Universiteit van Pretoria, uit dankbare erkentlikheid vir ondersteuning en aangename werkomstandighede. Dit het gedien as voordrag wat aangebied is voor die Hervormde Teologiese Vereniging op 20 Junie 2000, op die kampus van die Universiteit van Pretoria.
} 
waarom ek die historiese Jesus-ondersoek as wenslik reken en in die tweede plek bied ek 'n kort beskrywing van my profiel van die historiese Jesus. Vervolgens word oorgegaan na die diskontinuïteit en verband tussen die onderrig van Jesus en die verkondiging van die kerk dat die dood en opstanding van Jesus versoening tussen God en mens en mense onderling bewerk het.

\section{DIE WENSLIKHEID VAN DIE HISTORIESE JESUS- ONDERSOEK}

Enigiemand wat ' $n$ volgehoue interessse het in die historiese kritiek van die Nuwe Testament sal een of ander tyd aandag aan die historiese Jesus-vraagstuk móét gee. Historiese Jesus-navorsing help om groter duidelikheid te kry oor die proses hoe die tradisies oor Jesus in die Nuwe Testament oorgelewer is (vgl Van Aarde 2000b:11-16). Die historiese Jesus is óf die veronderstelde óf die uitdruklike vertrekpunt agter die ondersoek na die bronne wat die skrywers van die geskrifte in die Nuwe Testament kon gebruik het, die Sitze im Leben van hierdie bronne asook die teologiese tendense van die bronne en geskrifte van die Nuwe Testament. Die historiese Jesus-vraag vervul dus 'n betekenisvolle en onontbeerlike rol in die historiese studie van die Nuwe Testament. Dit is egter ook 'n kwessie van literêre en teologiese noodsaak.

Die erns maak met die genre van die evangelies bring mee dat die vraag na die verhouding tussen die voor-Pase en die na-Pase Jesus-tradisie nie vermy kan word nie. 'n Evangelie is die produk van 'n "redaktor-verteller". Met behulp van oorgelewerde tradisies, op ' $n$ herinterpreterende en skeppende wyse redaksioneel verwerk, kommunikeer die evangeliste in 'n verhaalvorm, soos storie-vertellers, hulle onderskeie perspektiewe op Jesus. In die oorlewering, omvorming en herinterpretasie van vroeëre tradisies is die voor-Pase Jesus-periode geprojekteer op die na-Pase periode van Jesus-gemeenskappe sodat twee historiese wêrelde tegelykertyd in die verhaalvorm van 'n evangelie opgeneem is. 'n Evangelie vertel dus van mense en dinge vanuit 'n vroeëre voor-Pase periode terwyl die latere na-Pase periode waarin die vertelling finaal ontstaan en gekommunikeer het, in die vertelde wêreld deursigtig is. Die wêreld van Jesus is meesal die deursigtigste, maar op sekere plekke in die evangelies is die wêreld van die na-Pase Jesusgemeenskap deursigtiger. Nooit manifesteer die wêreld van die verkondigde Christus egter geïsoleerd 
van die verkondigende Jesus nie. Met behulp van 'n histories-kritiese ondersoek kan die eksegeet tot op 'n sekere hoogte 'n onderskeid tref tussen die profiel van die historiese Jesus wat die eksegeet teken en die profiele wat die evangeliste oor Jesus geteken het. 'n Historiese ondersoek van die evangelies behels per definisie so 'n onderskeidingstaak.

Wie in die geskiedenis van die vroegste kerk geïnteresseerd is, is in 'n sekere sin verplig om die vraag na die historiese Jesus ernstig op te neem. Aan die ander kant kan niemand met die vraag na die historiese Jesus besig wees sonder om op een of ander wyse die verkondiging van die vroegste kerk ernstig te neem nie. Soos alle dialektiek is daar altyd sprake van kontinuïteit en diskontinuïteit - ook wat die verhouding tussen die historiese Jesus en die kerugmatiese Christus betref. Die Nuwe-Testamentikus wat met 'n historiese bewussyn wetenskap beoefen, kan die vraag na die aard van hierdie dialektiek nie systap nie. Die antwoorde op hierdie vraag het teologiese relevansie. Die dialektiese teoloog sal die kontinuïteit en diskontinuïteit tussen byvoorbeeld die dood van die historiese Jesus en die kerugma oor Jesus se opstanding en Jesus se gaan sit aan God se regterhand (soos gevind by o a Paulus) as van teologiese betekenis beskou. Die lewe van Jesus wat gelei het tot sy kruisiging, sal in ag geneem word wanneer gevra word na die relevansie van tekste soos Hosea $6: 2^{2}$ en Ps $110: 1^{3}$ wat gedien het as ondersteuning vir die volgelinge van Jesus se opstandings- en hemelvaartsgeloof. Maar die teoloë wat epistemologies neig na historiese positiwisme sal die diskontinuïteit sterk beklemtoon en daarop wys dat Jesus nie sy dood as 'n plaasvervangende versoeningsdood of vindikerende "martelaarsdood" gesien het nie en dat die kerugma as "toevoeging" (gerugsteun met beroepe op die Septuagint - kyk Funk \& The Jesus Seminar 1998:35) beskou moet word.

Ander teoloë wat neig na "kerugmatiese (openbarings-)positiwisme" ('n vorm van foundationalism - kyk Mouton \& Pauw 1988:177, 185-186) sal of nie geïnteresseerd wees in wat Jesus self oor die dood as sodanig gesê het en wat die aanleidende redes vir sy kruisiging kon gewees het nie ( $d$ w s 'n gebrek aan historiese kritiek en sosiale wetenskap) óf

\footnotetext{
2 "[Die Here] sal ons na twee dae 'n nuwe lewe laat begin. [Die Here] sal ons op die derde dag weer krag gee sodat ons in [die Here se] teenwoordigheid kan leef" (Hos 6:2).

3 “Die Here het vir my [Dawid se] koning gesê: 'Kom sit aan my [die Here se] regterhand, en Ek sal jou vyande aan jou onderwerp"” (Ps 110:1).
} 
sonder meer aanvaar dat daar in alle opsigte kontinuïteit tussen die kerugma en Jesus is, en dat die Nuwe Testament of die kerk se oortuigings oor versoening, opstanding en hemelvaart ooreenkom met wat Jesus gesê, bedink en gewil het ( $d$ w s 'n vorm van konfessionele teologie ${ }^{4}$ ). Wat ook al die epistemologiese vertrekpunt van die teoloog is - dialekties, historisties of konfessioneel - dit sal implikasies hê vir wat as basis van kerklike verkondiging en belydenis gesien word.

Een van die belangrikste teologiese redes waarom die historiese Jesus-vraag vir my noodsaaklik is ter wille van die geloofwaardigheid van die kerk, hou verband met die standpunt dat die kerk nie bó kritiek verhewe is nie. Die oortuigings van die kerk (afgesien waar dit neerslag gevind het: in die Bybel, dogmas, prediking of teologie) is gebind aan die saak waarvoor Jesus gestaan het. Die kerk is veronderstel om draer van die Jesussaak te wees. Dit is egter moontlik dat die kerk hierdie saak kan verduister. Dit kon gebeur het in die lewe van die vroegste kerk en dit kan vandag steeds gebeur. Dit kon gebeur het in die proses van die mondelinge oorlewering van die Jesus-tradisie en in die skriftelike fase toe die tradisie redaksioneel verwerk is en ook in die fase toe 'n geskrif as kanoniek aanvaar is.

Die historiese ondersoek na die Jesus-saak is dus vanuit 'n "etiese" perspektief (vgl Crossan 1998:19-40) noodsaaklik, nie net omdat mense uit die geskiedenis as sodanig waardevolle lesse kan leer nie, maar ook omdat niks wat in die geskiedenis gebeur het, 'n aanspraak het om van ondersoek gevrywaar te word as dit van publieke belang is nie. Jesus het 'n enorme invloed op die wêreldgeskiedenis gehad en navrae oor sy lewe maak meer sin as navrae oor die lewe van Aleksander die Grote of Napoleon Bonaparte. Daar is ook 'n ander kant van hierdie "etiese noodsaaklikheid" en dit is dat ook die kerugmatiese tradisie nie bó kritiek verhef is nie. Martin Luther ([1522:27] [1963] 1990:63] het vir ons getoon dat die kerk sulke kritiek nodig het om "gesond" te word wanneer die kerk (en samelewing) "siek" is.

Maar ook die rede (by name die historiese kritiek) is feilbaar. Daarom sal die vraag na die verhouding tussen die verkondigende Jesus en die verkondigde Christus oor

\footnotetext{
- Volgens die fundamentalistiese vorm van konfessionele teologie is daar nie net geen diskrepansie tussen dogma en Bybel (as Heilige Skrif) moontlik nie, maar genereer dogma regverdigmakende en reddende geloof. 'n Kritiese perspektief op dogma en Bybel (as Heilige Skrif) kom hiervolgens op "heidense ongeloof' neer. Dit is myns insiens 'n ope vraag of 'n konfessionele teoloog enigsins 'n histories-kritikus kan wees.
} 
en oor gevra moet word. Daar was nie 'n tyd in die geskiedenis toe hierdie vraag finaal en toereikend beantwoord was nie. Die uitdaging is om vir die teenswoordige tyd relevante en betekenisvolle antwoorde te vind. Dit sal telkens binne die eise van die teenswoordige pardigma moet geskied om relevant te kan wees. Daar kan nie meer as dit gedoen word nie. Veranderende tye bring veranderde antwoorde mee. Dit beteken egter nie dat vorige antwoorde noodwendig verkeerd was nie. Om te dink dat Christologie in die vierde eeu afgehandel is, of in die sestiende of twintigste eeu, kom op verraad neer teenoor Jesus se lakoniese ${ }^{5}$ wysheid en die evangeliste wat hulle kerugmatiese vertellings oor Jesus met verskillende oop-eindes afgesluit het. Of om te dink dat die reis saam met Jesus geëindig het met Albert Schweitzer ([1906] 1913) se ontbloting van die Old Quest, of Rudolf Bultmann (1965:190-198) se teenantwoord op Ernst Käsemann ([1954] 1960:187-214) se New Quest, of Thomas Wright ${ }^{6}$ (1992:12; 1996:80) se Third Quest versus Robert

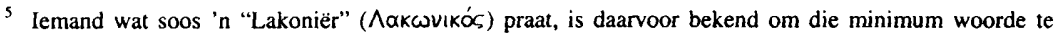
gebruik - selfs so saaklik dat dit as terughoudend of misterieus bestempel kan word.

6 Wright (1996:80) beskryf die "Renewed Quest" as die Wredebahn en die "Third Quest" as die Schweitzerstraße (-stream), verwysende na die twee opponerende weë wat Albert Schweitzer (1875-1965) en William Wrede (1859-1906) met betrekking tot die "historiese status" van die Markus-evangelie aan die begin van die 20 ste eeu ingeslaan het. Wrede het Markus beskou as ' $n$ teologie wat reeds ' $n$ apokaliptiese interpretasie van die historiese Jesus verteenwoordig, terwyl Schweitzer se posisie was dat die "Joodse eskatologie" in Markus ook Jesus se konteks verteenwoordig. Volgens Wright het die Wredebahn gelei tot die ondersoek na die Jesus-tradisie agter Markus en ander vroeë geskrifte soos die Spreuke-evangelie Q en die Tomas-evangelie. Wright haal Schweitzer aan uit sy The Quest of the Historical Jesus waar hy sê dat daar nie ' $n$ derde opsie moontlik is nie (tertium non datur) en suggereer dat die tyd toe die Wredebahn 'n "helpful fiction" was, nou tot 'n einde gekom het. In my boek Fatherless in Galilee het ek egter betoog dat daar wel 'n "derde opsie" moontlik is: "However, my interest in historical Jesus research is neither born from neoorthodoxy nor from neoliberalism. For me, it is a matter of urgency, if one would like to travel on the Schweitzerstraße, according to the designations of Albert Schweitzer himself, to prioritize and contextualize the sources that could lead to Jesus. Furthermore, it is in the 'subversive and dangerous memory of Jesus,' as David Tracy [1981:233-247] called it, that this road should be simultaneously, though paradoxically, also named the Wredebahn. Without a critical attitude of challenging the tradition, in other words treading along the Wredebahn, Schweitzer himself would never be guided by the 'cause of Jesus' to walk over from Strassbourg in Europe to Lambarene in Africa. He crossed over when he decided to become a physician in Africa. There is a third option, tertium datur!"
} 
Funk ${ }^{7}$ (1996:62-66) se Renewed Quest is om verward te wees oor die relevansie van die soeke na die historiese Jesus.

As Nuwe-Testamentikus het ek die verantwoordelikheid van betrokkenheid by hierdie soeke aanvaar en die dialektiek tussen die vraag na Jesus en die vraag na God in die lig van die teenswoordige paradigmaskuif nuut probeer beskryf en verduidelik. Die oorgang na 'n post-moderne paradigma is die konteks waarbinne hierdie werk gedoen word - en dit is die kerklike én die post-kerklike wêreld, die Christelike én post-Christelike of nie-Christelike wêreld.

\section{3. 'N PROFIEL VAN DIE HISTORIESE JESUS}

Ek het reeds op verskillende plekke 'n samevatting van die konstruk van die historiese Jesus wat uit my eie navorsing voortgevloei het, gebied. Sonder om weer in te gaan op die kenteorie agter en die metodologie van die literêre, historiese en teologiese aspekte van hierdie navorsing, vat ek hierdie profiel nou weer ter wille van die duidelikheid van my argument saam ${ }^{8}$ : Jesus was die seun van Maria wat deel van die landvolk was wat in die Galilese dorpie Nasaret gewoon het. 'n Vaderfiguur het nie in sy lewe 'n rol gespeel nie. Hierdie waarskynlike "feit" het 'n ingrypende invloed gehad op (a) die persepsie wat

\footnotetext{
7 Volgens Funk is die eksponente van die "Third Quest" alleen op grond van "historical curiosity" in die historiese Jesus geïnteresseerd: "The Christian faith was born, for them, with Peter's confession, or at Easter, or at Pentecost, or at Nicea....For third questers there can be no picking and choosing among sayings and acts as a way to determine who Jesus was. Instead, one must present a theory of the whole, set Jesus firmly within first-century Judaism, state what his real aims were, discover why he died, when the church began, and what kind of documents the canonical gospels are....The third questers...take critical scholarship about as far as it can go without impinging on the fundamentals of the creed or challenging the hegemony of the ecclesiastical bureaucracy. In their hands, orthodoxy is safe, but critical scholarship is at risk. Faith seems to make them immune to the facts. Third questers are really conducting a search primarily for historical evidence to support claims made on behalf of creedal Christianity and the canonical gospels. In other words, the third quest is an apologetic ploy" (Funk 1996:65).

8 'n Uiteensetting van hierdie konstruk word nie gebied nie - lesers kan daaroor meer lees in my Fatherless in Galilee: Jesus child of God wat in Maart 2001 deur Trinity Press International in die Verenigde State van Amerika (Harrisburg, Pennsylvania) uitgegee word. 'n Kompakte weergawe kan ook gevind word in my "Jesus als vaterlose Kind: Eine kuiturubergreifende und sozialpsychologisches Perspektive" wat opgeneem gaan word in die bundel Jesus in neuen Kontexten: Sozialwissenschaftiche Perspektiven der Jesusforschung, onder redakteurskap van Wolfgang Stegemann en wat in 2000 deur Kohlhammer Verlag (Stuttgart) uitgegee sal word. Goeie samevattings van my sienings kan ook gevind word in Donald Capps (2000:147-160) se boek, Jesus: A psychological biography, uitgegee deur Chalice Press (St Louis) en in die DD-proefskrif van Daan van Wyk (jnr) (2000), getiteld "Die relevansie van die historiese Jesus-ondersoek vir kerk en teologie: 'n Hermeneutiese vraagstelling", Fakulteit Teologie, Universiteit van Pretoria.
} 
mense van Jesus gehad het, (b) op Jesus se ervaring van God se teenwoordigheid as Vader in sy lewe en in die lewe van ander in wie se lewe 'n patriargale figuur ook nie 'n rol gespeel het nie en (c) op Jesus se interaksie met sulke deklasssierte Personen ${ }^{9}$ en met die élite. Jesus het nie getrou nie en hy was moontlik 'n ambagsman wat met hout gewerk het. Hy het in 'n spanningsverhouding met sy familie en die mense van Nasaret gelewe. Hy het by Johannes die Doper en die kring rondom Johannes aansluiting gevind, maar Hom van hulle losgemaak en self aanhangers rondom Hom versamel. Hy het na Johannes die Doper toe gekom om, in die lig van Jesaja 1:16-17, homself van (sistemiese) boosheid skoon te was. Die gevolg was dat hy 'n singewende rol in die lewe van mense begin vervul het - onder hulle was vroue en kinders wat na die rand van die samelewing gestoot was, die sosiaal-veragtes (weduwees, geskeides en wese, onreines en heidene) vir wie daar in die patriargale samelewing van post-eksiliese Israel nie plek onder die eerbares was nie. Nadat Jesus die kring van Johannes die Doper verlaat het, was sy lewe gekenmerk deur sy absolute afhanklikheid en vertroue in God as sy Vader. Die geringes in die Galilese samelewing was sy gehoor toe Hy met hulle oor sy Vader se koninkryk gepraat het. Hy het hierdie "skokkende" beeld vanuit die wêreld van maghebbers, eksploiteerders en manipuleerders in onkonvensionele terme in die taal van die landvolk verduidelik. Vir Jesus was God as 't ware soos 'n pater familias van 'n uitgebreide familie in 'n dorpie waar almal in so 'n kleinboerderygemeenskap direkte en onbemiddelde toegang tot die paterfamilias het. ${ }^{10}$ Vir die landvolk was Jesus soos 'n Gees-

\footnotetext{
9 Hierdie uitdrukking kom in Bultmann se samevatting van sy profiel van die historiese Jesus voor. Die res van die profiel lees soos volg: "Mit einiger Vorsicht also wird man über as Wirken Jesu Folgendes sagen können. Charakteristisch fur ihn sind Exorzismen, der Bruch des Sabbatgebotes, die Verletzung von Reinheitsvorschriften, die Polemik gegen die jüdische Gesetzlichkeit, die Gemeinschaft mit deklassierten Personen wie Zöllnern und Dirnen, die Zuneigung zu Frauen und Kindern; auch ist zu erkennen, daß Jesus nicht wie Johannes der Täufer ein Asket war, sondern gerne aß und ein Glas Wein trank. Vielleicht darf man noch hinzufügen, daß er zur Nachfolge aufrief und eine kleine Schar von Anhängern - Männern und Frauen um sich sammelte" (Bultmann [1960] 1965:11).
}

${ }^{10}$ Hierdie insig word veral deur Gerd Theissen ([1999], [1999] 1999:97-98) uitgewerk. 
gevulde messias, 'n wysheidsleraar en geneser, 'n populêre koning ${ }^{11}$ wat as 'n bedreiging deur Herodes Antipas ervaar was. Jesus was gesien as een van daardie profete wat konings krities aangespreek het. Sy wysheid was spreukagtig, skerp en memoriseerbaar. Sy stories was vol metafore, uitdagend, skokkend en het dikwels oop-eindes gehad. Sy optrede, veral sy genesings, kan ook as simbolies beskryf word wat daarop gerig was om mense aanvaarbaar vir God en vir mekaar te maak. ${ }^{12}$ Sy woorde en dade was radikaal kultuur-krities. ${ }^{13}$ Jesus het die Koninkryk van God nie in die eerste plek voorgestel as 'n katastrofale gebeurtenis in die toekoms wat hierdie-wêreldse lewe op 'n fantastiese wyse gaan vervang en wat vir die lydende regverdiges as 't ware 'n militêre oorwinning oor hulle goddelose vyande gaan beteken nie. Hy het dit ook nie met aardse koninkryke vergelyk waar menslikheid agter simbole van mag en hièrargie verdwyn nie, maar as 'n huishouding waar troebel verhoudings in mede-lyde en mede-vreugde herstel word en waar God teenwoordig is. Jesus se subversiewe wysheid het die hart van die Tweede Tempel se reinheidsideologie aangetas - 'n radikaal onkonvensionele benadering wat nie ten volle deur prominente leiers onder die dissipels verstaan is nie, maar wel deur iemand wat Hom nie persoonlik geken het nie. Dit was Paulus wat die implikasies van Jesus se evangelie vir dieet, besnydenis en kalender uitgewys het - implikasies vir 'n lewe in heiligheid voor God en in geregtigheid teenoor mekaar. Jesus het as gevolg van hierdie benadering in konflik gekom met leiers van Galilese dorpe en Fariseërs wat op besoek vanaf Jerusalem was. In Jerusalem is Hy deur Saddusese hoëpriesters, familiehoofde en priesterlike élite as 'n bedreiging ervaar en na 'n provokasie in die voorhof van die tempel is Hy deur Romeinse soldate as 'n onrusstoker gekruisig. Hy is nie deur familie of vriende in 'n familiegraf begrawe nie. Jerusalem as sodanig was sy "begraafplaas".

\footnotetext{
"Kyk veral die werke van Richard Horsley (\& J S Hanson), Bandits, prophets, and messiahs: Popular movements in the time of Jesus (1985) en Jesus and the spiral of violence: Popular Jewish resistance in Roman Palestine (1987).

${ }^{12}$ Kyk veral Van Aarde (2000c), "Understanding Jesus' healings" wat in Scriptura gepubliseer sal word.

13 Hierdie insig is uitgewerk in Van Aarde (1996), "Kultuurkritiek, eerste-eeuse kulturele wysheid en die alternatiewe visie van Jesus van Nasaret" wat in HTS 52(4), 833-849 gepubliseer is.
} 
Hier het die eerste kultiese gemeenskap van Jesus-volgelinge die doop van Johannes die Doper as 'n "doop in die Heilige Gees" geherinterpreteer en dit verstaan as inisiasie tot die "eskatologiese Israel" wat deur die "twaalftal" verteenwoordig word. In Jerusalem is die "laaste maaltyd" van Jesus met sy dissiples omvorm in 'n "eskatologiese" maaltyd. Hierdie institusionalisering was gegrond in die kerugma dat God Jesus uit die dood opgewek het. Die opgestane Jesus het aan sekere mense (o a Maria Magdalena, Petrus, Jakobus en Paulus) verskyn. Binne 'n na-Pase kultiese konteks het volgelinge begin praat van Jesus se messiaanse verhoging tot mag, bewyse daarvoor in die Heilige Skrifte gevind, Hom met verskillende erename vereer en sy hemelse verhoging in terme van die Hellenisties-Semitiese en Grieks-Romeinse leefwêreld beskryf. Sy opstanding, verskyning en verhoging was 'n werklikheid soos sy dood 'n werklikheid was - hoewel ons op grond van ons kennis van onder andere die apokaliptiek en die gnostiek van verskillende dimensies van werklikheid moet praat.

\section{DIE HISTORIESE JESUS EN DIE KERKLIKE KERUGMA}

In die Mediterreense wêreld het die naam "Jesus" algemeen voorgekom en dit is vandag onder Christene in daardie wêrelddeel steeds die geval. Wanneer Christene in SuidAfrika die naam "Jesus" hoor, dink hulle waarskynlik aan "God". Diegene wat nie oor die histories-kritiese resultate van die Nuwe-Testamentiese wetenskap ingelig is nie, makk gewoonlik ook nie 'n onderskeid tussen die name "Jesus" en "Christus" nie. Dit was anders in die leefwêreld van die Bybel waar die koning van Israel God se "christus"/"messias" genoem is (kyk Ps 2:2; PssSol 17:21-27; 18:5-9) en nie Jesus van Nasaret nie. Ook in die periode van die Tweede Tempel is verskeie rebelleleiers in die Galilese kleinboerderygemeenskap as "messiasse" gesien (kyk oa JosBell 1.204-207; JosAnt 14.159-179; vgl ook Mark 13:21-22). Paulus verwys wel na Jesus as "Christus Jesus", maar in die Spreuke-evangelie Q word Jesus glad nie "Christus" genoem nie (kyk Tuckett 1996:214). In die Markus-evangelie was Jesus ongemaklik as daar na Hom as die "Christus" verwys is (kyk Den Heyer 1996:78-80). In die Nuwe Testament word 
"Christus" nie sonder meer "God" genoem nie (kyk Bultmann [1958] 1968:131 nota 1). Hierdie assosiasie word eers in die 2 de eeu $\mathrm{n}$ C by Klemens, kerkvader van Aleksandrië (kyk Protr 1:1), en by Ignatius, kerkvader van Antiogië (kyk Ign Trall 7:1; Ign Smy 1:1; 10:1) aangetref. Die belydenis "Jesus is God" is dus deel van die na-Nuwe-Testamentiese laatkerugmatiese tradisie. ${ }^{14}$ In 'n ander artikel het ek wel aangetoon dat die wortels van die dogma oor die twee nature van Jesus, ware mens en ware God, nie net in die kerugmatiese tradisie gegrond is nie, maar in 'n sekere sin in die historiese Jesus self (kyk Van Aarde 1999:437-470).

Hierdie argument hou verband met my standpunt oor die relevansie van die historiese Jesus vir kerklike teologie. Vir die doeleindes van hierdie voordrag is kerklike teologie vir my die kerugmatiese tradisie dat God op grond van die kruisiging en opstanding van Jesus die mens met God versoen het. Hierdie tradisie kan myns insiens na die vroegste gemeenskap van na-Pase Jesus-volgelinge in Jerusalem teruggevoer word. Dit is ook die sentrum van Paulus en die "Pauliniese skool" se soteriologie en dit word ook by ander belangrike Nuwe-Testamentiese getuies aangetref soos onder andere Markus, Lukas, Matteus en Johannes. Dit is die vertrekpunt van 'n kerkvader Irenaeus (Demonstration/Epideixis; Adversus haereses - kyk Oetting [1964] 1970:58-60). Dit word op 'n besondere wyse deur Anselmus van Canterbury (Cur Deus homo?, xi, in Bettenson 1967: 138-139) uitgewerk, deur die Heidelbergse Kategismus (kyk Haitjema 1962:96-101) heropgeneem, deur Schleiermacher ([1830] 1928:68-76; kyk Clements 1987:108-123) on-

\footnotetext{
14 In Fatherless in Galilee het ek my soos volg hieroor verantwoord: "When believers in the first and second centuries referred to Jesus as God's Christ, as God's equal, as Child of Humanity, or as God's image which manifests God, or as Child of God who comes forth from God, or who is legitimated by God, or who was with God, or who emanated from God's 'fullness' (attested to in Gnostic literature), they used recognized metaphors. Precisely the same happens when Christian believers today speak about Christ (meaning Jesus) as though they are speaking about God. Understood thus, the term 'Christ' is a metaphor for God like the term 'Krishna' is a metaphor for God. I am not saying that Krishna is God to me. On the contrary, I would like to emphasize that, to me, Jesus Christ is not only $a$ but the manifestation of God. If a decontextualized view is possible in this instance, one could say that there are different manifestations of God. Such a cognizance, however, is only true in an abstract sense. It could, however, present a proper observation of those cultural environments where people have been socialized into polytheism or into Godtalk in terms of multi-religiosity, such as Hinduism and Taoism. Socialization into a strict monotheistic mind-set (as Christianity always has been in spite of its syncretistic assertions borrowed from the pagans) makes it almost impossible for a Christian believer to refer to Christ as $a$ manifestation of God. (This is not about worshipping a triune God.) Jesus Christ is always the manifestation of God, though Christianity since its earliest origins made use of terms by which God-like figures and figurines have been referred to within a polytheistic mind-set (Van Aarde 2001).
} 
verkort in nie-tradisionele terme gehandhaaf, ${ }^{15}$ deur Barth (1960:171-231, 231-311; kyk Van Zyl 1999:414-417) verder gevoer en by Bultmann in Paulus (kyk Bultmann 1952: 285-287) en Johannes (kyk Bultmann ${ }^{16}$ [1964] [1966] 1971:9) teruggevind.

My standpunt is dat daar ' $n$ verband en ' $n$ diskontinuitteit tussen die historiese Jesus en die kerklike teologie is. Daar is 'n inhoudelike diskontinuïteit tussen die wysheidstradisie van die historiese Jesus en die sentrum van die apokalipties-bepaalde kerugmatiese tradisie oor die versoening op grond van die kruisiging en opstanding van Jesus. Historiese Jesus-navorsing kan dit nie bevestig dat Jesus se onderrig oor die Koninkryk van God as 'n katastrofale apokaliptiese gebeure verstaan moet word nie (kyk Crossan

\footnotetext{
15 Clements (1987:57) beskryf hierdie "nie-tradisionele" terme soos volg: "Redemption and reconciliation are founded in this union [personal communion with Jesus], not in any extra-personal transactions or ransom-payments or penal satisfactions for sin, as in certain traditional theories of atonement". Hierdie standpunt moet egter nie so verstaan word dat Schleiermacher van mening sou wees dat mense self enigiets tot hulle heil kan bydra nie. Clements (1987:54-55) maak die volgende opmerking: "Protestant liberalism has often been charged with reducing the historical Jesus to a moral and spiritual example or hero, in contrast to the one who saves lost [hu]mankind by his sacrifice. Schleiermacher's Christ, however, does not just serve as a spur to moral endeavour. His opening christological thesis runs: 'If the spontaneity of the new corporate life is original in the Redeemer and proceeds from him alone, then as an historical individual he must have been at the same time ideal (i.e. the ideal must have been completely historical in him), and each historical moment of his experience must at the same time have borne within the ideal' [Schleiermacher [[1830]] 1928:377]. The new life is not generated by the believer, or by the community itself, but is actually imparted through communion with the Jesus in whom it has its source and who is its 'ideal realization'. It must be noted, however, that when Schleiermacher speaks of 'ideality' (Urbildlichkeit) he does not mean an abstract model of perfection, but something nearer the Platonic 'form', that which actually imparts reality to a particular object which participates in it. Also, while Schleiermacher speaks of the 'exemplary' status of Jesus (Vorbildlichkeit) he does not mean a kind of model to be copied, but rather the way in which Jesus himself exemplified the human race by solidarity with it in the fullness of humanity" (my beklemtoning).
}

${ }^{16}$ Hoewel Bultmann ([1964] [1966] 1971:218-219, 234-237) meen dat die "nagmaalswoorde" in Joh 6:2759 en Joh 6:51b-58 die produk van 'n latere "kerklike redaktor" was, sê hy ten opsigte van Joh 8:34 die volgende: "[Humankind] can receive freedom from [it]self only as present, as eschatological gift; [s]he cannot acquire it him[her]self. For everything that [s] he undertakes of his own accord is determined from the first through that which [s] he already is. Only [s] he who could act under the motive of that which [s] he is not would be free; but that means: freedom is only an eschatological possibility, given by God through revelation. Its conception however presupposes the admission that one is a bondman [ $\delta \circ \bar{\lambda} \lambda \propto 5$ ], a slave to one's own past, to the world, to sin" (Bultmann 1971:439). 
1996:51-75). Historiese ondersoek het wel bevestig dat dit hierdie onderrig was wat daartoe gelei het dat Jesus verwerp en doodgemaak is. ${ }^{17}$

Die stelling kan gemaak word dat Jesus werklik gesterf en werklik uit die dood opgewek is. Die kruisiging is terug te voer na die werklikheid van Jesus se onkonvensionele wysheid wat as aanstoot ervaar is. Die opstanding is terug te voer na die werklikheid (simboliese universum) van die apokaliptiek waarvolgens God die lydende regverdige vindikeer (kyk Collins 1984; 1985:105). Die eerste is deel van "ervaarde tyd" en die tweede is deel van "verbeelde tyd"18 (kyk Malina 1996:179-214). "Verbeelde tyd" kan ook in sosiaal-wetenskaplike terme beskryf word as 'n "alter staat van bewussyn". Die begrip "tyd" wat hier vir beide dimensies ("ervaarde tyd" en "verbeelde tyd") gebruik word, is uitdrukking van die werklikheid van Jesus se kruisiging én opstanding/verhoging. Historiese Jesus-navorsing bevestig ook die waarskynlike historisiteit daarvan dat sekere volgelinge van Jesus binne hulle ervaarde werklikheid die gevindikeerde opgestane Jesus gesien het en dat ander hulle kerugma óf betwyfel of aanvaar het (kyk The Fourth $R$ 1995:12-17).

Die "werklikheid" van die apokaliptiese mitologie het ook die paradigma van die opstellers van die Reformatoriese belydenisskrifte help vorm. In die uitsprake oor die

\footnotetext{
${ }^{17}$ Crossan (1995:490 formuleer dit soos volg: "Jesus called his program [sic] the presence of the Kingdom of God, but that expression must be interpreted primarily in light of what he himself did and what he also challenged his companions to do. It did not mean for Jesus, as it could for others, the imminent apocalyptic intervention of God to set right a world taken over by evil and injustice. It meant the presence of God's Kingdom here and now in the reciprocity of open eating and open healing, in lives, that is, of radical egalitarianism on both the socioeconomic (eating) and the religiopolitical (healing) levels. That combination of vision and program, of word and deed, of thought and action could easily have led to Jesus' as it had to John's execution by Antipas".

${ }^{18}$ In my boek Fatherless in Galilee het ek dit soos volg geformuleer: "Present-day studies on apocalyptic eschatology reveals a 'sectarian mentality' (see, among other publications, Collins, J.J. 1984, The Apocalyptic Imagination: An Introduction to the Jewish Matrix of Christianity): in a crisis, a minority group becomes marginalised, tending to be aware of only two sides of a matter (dualism): the right and the wrong, the divine and the satanic, a world here and now and a world beyond. As is well known, the worldview of the apocalyptic is marked on the one hand by pessimism and determinism, and on the other by hope: the present dispensation is a miserable dispensation, while the transcendent dispensation beyond this one is joyful. Such pessimism and determinism are relativized by the conviction that the course of history may be changed, for the sake of the self and others, by means of the prayers and martyrdom of the 'righteous.' The crisis in the cultural world of Israel and the church, which gives rise to this, revolves around the pressure which heathen powers placed on the cult and the being of the church. The crisis is magnified because the presumed relation between deed and retribution is not realised. The godless are not punished and the righteous are not visibly the victors. Seen from Bruce Malina's study ('Christ and Time: Swiss or Mediterranean?', 1996, pp. 179-214), 'experienced time' is as a result of this embarrassment projected into an 'imaginary time' in which God exercises control".
} 
opstanding/verhoging van Jesus gaan dit hier om die dood wat oorwin is en dat gelowiges deel het aan die geregtigheid van God wat deur Christus bewerk is (Heidelbergse Kategismus, 45a). In dieselfde geloofsartikel word verder beklemtoon dat ons as gelowiges reeds 'n "nuwe lewe" het (Heidelbergse Kategismus, 45b) en verder in dieselfde belydenisskrif dat ons tot waaragtige bekering gemaan word (Heidelbergse Kategismus, 88-91). In hierdie opsig kom die belydenis van die kerk ooreen met die getuienis van veral Paulus. Ons word verder in die Heidelbergse Kategismus herinner aan ons "eie salige opstanding" (Heidelbergse Kategismus, 45c). In hierdie selfde verband word die uitdrukking "opstanding van die vlees" in verband gebring met 'n ou Grieks-filosofiese vraag of net die "siel" deelkry aan die "salige hiernamaals" of die "hele liggaam" (Heidelbergse Kategismus, 57). Ons weet egter dat toe die vroegste Christendom nog binne die Jodedom ingebed was, hierdie tipe tweedeling in die Griekse denke vreemd vir gelowiges sou gewees het. In ' $\mathrm{n}$ ander verband, in die Nederlandse Geloofsbelydenis (NGB), word "ons eie opstanding" afhanklik gemaak van die "egtheid" dat Jesus self eens tussen die mense was (NGB, 19). En ten slotte, juis op grond van die opstandingsgeloof, verlang die kerk belydend en sterk (omdat gelowiges met heerlikheid gekroon sal word) na die verwerkliking van die ewigheidsdimensie (NGB, 37).

Vandag is ons mense geneig om vanweë ons empiriese denke die krag van hierdie belydenis van die opstanding en die moontlikheid van ons eie opstanding vas te maak aan die feitelikheid ('n historiese gebeurtenis ante nos of as 'n ontologiese gebeurtenis extra nos) van Jesus se opstanding uit die dood. "Feit" beteken in hierdie verband factum brutum, iets wat kontroleerbaar werklik sou gebeur het. Veral 1 Korintiers 15:13-14 word in hierdie verband as bevestiging hiervan verstaan. Wanneer ons dit doen, verwar ons wat Karl Barth Urgeschichte genoem het (en ek "verbeelde tyd"), met Geschichte (of te wel "ervaarde tyd"). Ons sien ook nie, soos Rudolf Bultmann dit sou uitdruk, die "objektivering van mitiese spreekwyse" raak $^{19}$ nie. Indien ons die verskillende berigte oor die opstanding (as "objektivering van mitiese spreekwyse") in die Nuwe Testament

\footnotetext{
19 Bultmann ([1928] 1969c:83) verduidelik sy raakpunt en verskil met Barth ([1924] 1933:139) soos volg: "With this interpretation, Barth has supported his contention that [1 Cor 15:] vv. 3f. are not intended to be an historical account...But it is plain that for Paul the resurrection of the dead was accepted also as an historical fact...I [Bultmann] can understand the text only as an attempt to make the resurrection of Christ credible as an objective historical fact. And I see only that Paul is betrayed by his apologetic into contradicting himself' (beklemtoning deur Bultmann).
} 
en ander vroeg-Christelike geskrifte ${ }^{20)}$ aan histories-kritiese ondersoek onderwerp, dit wil sê op soek na wat het werklik in die geskiedenis gebeur (Geschichte en nie Urgeschichte nie), sal daar gou gestuit word voor vrae soos (kyk Funk 1994:3-16; Sheehan 1995:6-7): wie het nou werklik op die opstandingsdag na Jesus se graf gegaan, wanneer presies is daar gegaan en waarom is daar gegaan? Die probleem is egter dat die diverse gegewens in die Nuwe Testament nie 'n eksakte historiese beslissing toelaat nie! Dieselfde geld vir 'n vraag soos: hoeveel engele is in of rondom die graf gesien? Wat het die engel of engele aan die vroue gesê? Wat het die vroue gedoen na hulle ontmoeting met die engele? Wie het eerste die opgestane Jesus gesien? Hoe dikwels het die opgestane Jesus aan die dissipels verskyn, aan watter dissipels, waar en wanneer? Gaan die opstanding van Jesus gepaard met sy gawe van die Heilige Gees aan die dissipels, en indien wel, wanneer het dit gebeur? Wanneer het die opgestane Jesus sigbaar en liggaamlik ten aanskoue van die dissipels opgevaar (net Lukas berig so): op Paas-Sondag of veertig dae later op Hemelvaart-Donderdag? (Lukas berig beide datums.)

Lees ons egter die getuienis in die Nuwe Testament oor die opstanding van Jesus as die "objektivering van mitiese spreke" sien ons dat Jesus se opstanding vir die vroegste kerk nie op 'n resussitasie, 'n terugbring tot die lewe ("ervaarde tyd") neergekom het nie. Die opstanding van Jesus is nie 'n terugkeer na die "werklikheid" van hierdie aardse lewe nie (kyk Wilckens 1988:185). In die terme van die apokaliptiese leefwêreld van die Nuwe Testament word gelowig getuig dat 'n nuwe lewe voor God, en uiteindelik dus ook by God, deurgebreek het. Met ander woorde, die geloof van die dissipels en daarmee saam ook ons geloof, is vandag nie alleen maar die aanvaarding van 'n historiese feit wat deur kontrolerende metodes bevestig en in 'n hof getoets sou kon word nie ('n historiese gebeurtenis ante nos). Tog is die opstanding 'n geloofswerklikheid binne die Goddelike sfeer (maar nie in die sin van 'n ontologiese gebeurtenis extra nos nie).

Watter implikasies het die belydenis van die opstanding vir gelowiges vandag wie se denke deur die natuurwetenskap gevorm is? Die opstandingsgeloof hoef nie vandag noodwendig in apokaliptiese kategorieë en metafore uitgedruk te word nie. Die

\footnotetext{
20 Die volgende tekste is ter sprake: 1 Kor 15:3-8; 1 Kor 15:40, 42, 44, 47-48, 50; Mark 16:1-8; Matt 28:120; Luk 24: 1-53; Hand 1:1-11; Joh 20:1-31; Joh 21:1-23; EvangPetrus 9-14; EvangHebr 9; Pseudo-Mark 16:9-20; Mark 9:2-8//Matt 17:1-8//Luk 9:28-36; Luk 5:1-11; Hand 9:3-19; 22:1-16; 26:9-18; Hand 7:55-56; Openb 1:13-16.
} 
Johannese literatuur bevat uitsprake wat kan dien as voorbeeld van 'n uitdrukkingswyse waar die opstandingsgeloof nie in terme van die apokaliptiek verwoord is nie. Die belydenis van die opstanding wil sê dat om "opnuut gebore te wees" (Joh 3:3) of om "uit die dood na die lewe oor te gaan" (Joh 5:24) 'n totale nuwe bestaansvorm is: 'n nuwe bestaanswyse waarin God die eindige in die oneindige, die tyd in die ewigheid, hierdietydse in sinvolle hede en toekoms, verander. ${ }^{21}$ Die opstandingsgeloof verwoord die afsterwe van die mens se poging om die heil in die mens self of in enige ander objektiewe kategorie (bv in formules, tekste, dogmas, taal, herkoms, nasionaliteit, etnisiteit) te soek. Dit verwoord tegelykertyd die imperatief om vanuit die geloof alléén as ons enigste sekerheid te lewe.

\section{DIE KERKLIKE KERUGMA OOR JESUS SE VERSOE- NINGSDOOD}

Binne die verwysingsraamwerk van die apokaliptiek, en in terme van volgelinge van Jesus se sosiale wêreld en eksegese van Ou-Testamentiese gedeeltes, is Jesus se sterwe as 'n plaasvervangende en versoeningsdood verstaan. Hoewel daar ' $n$ inhoudelike diskontinuïteit tussen die woorde en dade van Jesus en die kerklike kerugma aan te toon is, meen ek dat daar 'n saaklike verband tussen die twee bestaan. Hierdie relasie kan as die relevansie van historiese Jesus-navorsing vir kerklike teologie gesien word. Ek gaan vervolgens hierdie relasie in terme van die kerk se siening oor Jesus se versoeningsdood bespreek.

Ek het reeds gewys op die inhoudelike diskontinuïteit tussen die onderrig van Jesus en die kerk se boodskap oor die versoening op grond van sy dood en opstanding. Wat is egter die saaklike verband tussen Jesus se onkonvensionele, subversiewe wysheid en die versoeningsboodskap van die kerk? In 'n ander bydrae het ek betoog dat die Pauliniese stelling dat die lewe alleen op grond van die geloof moontlik is en nie op grond van die nakom van die bepalings van die Mosaïese wet nie, 'n bondige en saaklike

\footnotetext{
21 "What must be investigated is the meaning of the concept 'life' in the Gospel of John. An understanding of that concept can be gained from an insight onto the so-called 'dualism' of the Gospel. Life belongs to the realm of God; death to the realm of the world. But what does world mean in the Gospel of John?... '[T]o be world' means first of all for [human beings] that they are created" (Bultmann [1928] 1969a:166167).
} 
samevatting van die subversiewe wysheid van Jesus is. Paulus het hierdie stelling gegrond op sy oortuiging dat die dood van Jesus die afsterf van die vereiste van die nakoming van die wet is en dat die opstanding die begin is van die lewe van die "nuwe mens" ( 2 Kor 5:17). Hoewel Jesus nie sy dood so verstaan het nie, het sy woorde en dade op dieselfde neergekom. ${ }^{22}$ Hierdie lewe van Jesus het gekondenseer in sy dood. Die boodskap van Jesus dat die lewe nie daaruit bestaan om hierdie-wêreldse as wins te hê nie, is ook die kern van die boodskap dat God nuwe lewe skep wanneer hierdie-wêreldse afgesterf word.

Die boodskap van Paulus (kyk 2 Kor 5:18-21) oor die versoening wat God tussen God en mens en tussen mense onderling op grond van die dood en opstanding van Jesus bewerk het, onderstreep Jesus se subversiewe "wysheid". (Op ander plekke gebruik Paulus uitdrukkings soos "vir ons gesterwe" [Rom 4:24-25] en "gekoop en betaal" [Gal $3: 13 ; 1$ Kor $6: 20 ; 7: 22]$.) Jesus het geleer dat outentieke lewe nie daarin bestaan dat mense hulle eie heil kan bewerk of dit in konvensies, kultuur, herkoms of enigiets wat hierdie-wêrelds is, kan vind nie. Wanneer hierdie wysheid dat die heil van buite die mens is, in woorde uitgedruk word, sal egter beelde, simbole en metafore gebruik word wat sin maak binne bepaalde konvensies en kultuur. Die apokaliptiek was die dinkraamwerk waarbinne die vroegste Jesus-groep hierdie wysheid uitgedruk het. Die Jesus-volgelinge het ook in terme van hulle verstaan van gedeeltes soos Jesaja $53^{23}$ en in terme van die konvensie van die offerritueel in die tempel uitdrukking gegee aan hoe hulle die ver-

\footnotetext{
22 Bultmann ([1928] 1969b:230) formuleer dit soos volg: "It is clear that Jesus did not present this kind of explicit theological reasoning. But it seems to me equally clear that by it Paul simply explains and clarifies the thought of Jesus by the use of specific historical antitheses. The reasoning is certainly based on the same fundamental motive, which was the foundation of Jesus' polemic: the opposition between legal right and the true will of God. That opposition is the reason for Jesus' polemic; God's will cannot be enshrined in legal enactments which man can discharge, so that he could exhibit his achievements before God and present a claim... What Jesus does not state is that from the beginning it is impossible for the law at any time to confront [humankind] who desires to gain security by his own achievements in any other way than his 'custodian'. But however remote this theological idea may be from Jesus' preaching, that preaching does actually imply it. This can be recognized in the fact that Jesus sees and says the officially religious, the 'righteous', are not willing to listen either to the Baptist's call to repentance or to his own, while the tax-collectors and harlots, the 'sinners', listen (Matt. 21.32; Luke 7.29)" (beklemtoning deur Bultmann).

23 "Tog het hy óns lyding op hom geneem....deur sy wonde het daar vir ons genesing gekom...Soos 'n lam wat na die slagplek toe gelei word....Hy is gestraf oor die sonde van my volk...As hy sy lewe as skuldoffer gee, sal hy 'n nageslag hê en nog lank lewe... Daarom gee Ek hom 'n ereplek onder die grotes. Hy sal saam met die magtiges die oorwinning vier omdat hy hom in die dood oorgegee het...omdat hy die sondes van baie op hom geneem het" (Jes 53:4, 7, 8, 10,12).
} 
soening verstaan het. Dit is binne hierdie konteks dat Paulus (1 Kor 5:7-8) ook na Jesus as "ons paaslam" verwys. Paulus het egter hiermee nie die klem op 'n bloedtoneel geplaas nie. Hy het met hierdie beeld, "Jesus is ons paaslam", verduidelik dat Jesus die heilige/reine/heel/passende by God/beeld van God is en dat sy dood aan die kruis en sy opstanding die herskepping van gelowiges moontlik maak (kyk Den Heyer [1998] 1998:57-73). Paulus het ook gesê dat Jesus die "versoendeksel" is (Rom 3:23-25). Die versoendeksel het op die jaarlikse Groot Versoendag 'n belangrike rol gespeel (kyk Eks 25:16-20; Lev 16:14-16). Dit was die plekaanduiding van God se teenwoordigheid in die allerheiligste van die tempel (kyk Wenham 1995:152). Om Jesus as die versoendeksel uit te beeld, argumenteer Paulus dat God op Golgota en nie in die tempel nie, vir alle mense teenwoordig geword het. ${ }^{24}$ Dit beteken dat mense (soos die heidene - of volgens die evangelies ander gemarginaliseerdes) wat vroeër van die tempelgebruike uitgesluit was, nou ook toegang tot God gekry het. Hierdie boodskap toon 'n saaklike verband met die wysheid van Jesus. Wanneer Paulus Jesus se dood as "versoening" beskryf, het hy die sosiale gebruik (wat tot vandag by mense in die Bybellande aangetref word) in gedagte dat daar van buite 'n tussenganger nodig is om versteurde verhoudings reg te maak. Weer eens is dit die beklemtoning dat mense self nie die vermoë het om die beskadigde verhouding tussen God en mens en tussen mense onderling reg te stel nie. God doen dit deur en in Jesus ${ }^{25}$.

Anselmus van Canterbury (Cur Deus homo?) en die Heidelbergse Kategismus (Sondagafdeling 15, Vraag en antwoord 35 en 39) het in terme van die mensbeskouing van daaraan tyd (die kultuur van diadiese persoonlike relasies) hierdie beelde uitgebrei en daaraan toegevoeg. Volgens die sosiale gebruik van daardie leefwêreld (wat nie wesenlik

24 Käsemann ([1973]1974:91) gebruik die uitdrukking "öffentliche Manifestation" en Barrett ([1957] 1967:77) vertaal Rom 3:25 soos volg: “This Christ Jesus God publicly set fort [ $\pi \rho \circ \varepsilon^{\prime} \theta \varepsilon$ то; $\pi \rho \circ-$ in composition often signifies 'publicly'] in his bloody 'sacrificial death' as his means of dealing with sin, received through faith" (my beklemtoning). Celliers Breytenbach (1986:698) maak die volgende opmerking: "As ons Romeine 3:25 in hierdie lig lees, word dit 'n uitspraak wat teenoor die tempelkultus staan. Die plek van God se genadige teenwoordigheid is nie meer die tempel nie, maar God het Christus openlik opgerig as die plek waar [God] mense van die gevolge van hulle sonde verlos."

25 Martyn (1997:144) formuleer dit soos volg: "Rectification is now accomplished, however, not by a sacrifice executed by a human being (such as the high priest acting on the Day of Atonement), but rather by Christ's death. And in this Jewish-Christian tradition, that death is understood to have been God's sacrificial act taken at his initiative. It is the deed in which God has forgiven the sins formerly committed in Israel, wiping the slate clean (Rom 3:25)." 
van die leefwêreld van die Bybel verskil het nie) het die herstel van beskadigde verhoudings tussen mense veronderstel dat daar 'n gebaar van regstelling aan die persoon in onreg moet plaasvind. ${ }^{26}$ So kan die dood van Jesus gesien word as die bewys van regstelling aan God wat toornig is oor die sondes/verkeerdhede van Israel. Ou-Testamentiese tekste is gebruik as ondersteuning van hierdie siening. Die Heidelbergse Kategismus verduidelik in aansluiting by die Nuwe Testament dat hierdie regstelling nie kan plaasvind op grond van die vermoë van die sondaar nie, maar dat die dood van Jesus (as ware God) die genadedaad van God van buite die mens is en dat die gekruisigde Jesus (as ware mens) tegelykertyd die mens is wat in die regte verhouding met God lewe. ${ }^{27}$ Ons kry in die geloof deel aan Jesus. Ons deelname aan sy sterwe en opstanding maak ons herstelde/herskepte mense.

Die Efesiër-brief (4:17-24) beskryf op grond van Paulus hierdie "waarheid" as die "waarheid wat in Jesus" is. In hierdie brief word gesê dat die lesers van die brief (gelowiges wat vanuit die heidendom tot die Christendom bekeer is) reeds onderrig is oor die waarheid wat daar in Jesus is. Die teleurstelling is egter dat hulle lewe soos heidene wat volhard om heidene te wees en dit is 'n lewe sonder die "heiligheid" en "geregtigheid" waarop die "waarheid" betrekking het. Heidene wat as heidene volhard, is mense sonder Christus (en daarom sonder God), maar ook in terme van die Ou Testament sonder die seremonies ("verbonde"), maar ook sonder die "beloftes" van die seremonies (kyk Ef 2:11-18). Maar heidene kan weet dat hulle op grond van God se werk naby God kan kom en nie meer ver en verwyderd van God te midde van die beskadigde verhouding met God en met mekaar hoef te leef nie. Heidene het naby God gekom omdat Jesus se "liggaam gebreek" is en sy "bloed gestort" is (kyk Ef 2:13-14). Die sterwe van Jesus het die seremonies van die wet opgehef (Ef 2:15) - mense wat vroeër nie toegang tot God gehad het nie, het nou toegang verkry. God se Gees bewerk dit, nie hulleself nie! Die opheffing van die seremonies is ook die begin van 'n nuwe skepping - mense hoef nie meer sekuriteit en saligheid in die geskapenheid te soek nie; nie meer in die kultuurkonvensies nie en dit maak nie meer saak of 'n mens 'n Jood of Griek is nie, man of vrou, slaaf of

\footnotetext{
26 Kyk Spreuke-evangelie $Q$ (12:58) vir tipiese maatreëls oor vergelding en versoening waarvan die "grondteks" in Lev 19:17-18 te vind is (kyk Catchpole 1993:115-116).

27 Vir Karl Barth se refleksie hierop, kyk Van Zyl (1999:413-414).
} 
vry nie (Gal 3:28)! In Christus is 'n eenheid bewerk (Ef 2:15). Die dood van Jesus het 'n skeidsmuur afgebreek (Ef 2:14); vyandskap met God en met mekaar is beëindig (Ef 214). Vesoening is bewerk (Ef $2: 16)$ !

Die teleurstelling is egter dat die Efesiërs wat nie meer heidene is nie, steeds soos heidene lewe (Ef 4:17) - sonder Christus, sonder die waarheid wat in Jesus is, sonder die heiligheid (geskape soos God wil) en die geregtigheid (die doen van barmhartigheid as instrument van God se liefde) wat op grond van hierdie waarheid moontlik gemaak is (vgl Schlier 1957:221-222). Die Efesiërs weet mos wat die waarheid is waaroor hulle onderrig is! Steeds laat hulle hulle lewe bestuur deur die gewoontes van die geskape wêreld en die konvensies van hierdie wereld. Hulle het nie die ou klere uitgetrek en nuwe klere aangetrek nie (Ef 4:24). Hulle innerlike is nie vernuwe nie (Ef 4:23)! Hulle is nie wat hulle geword het nie: geskape soos God wil (Ef 4:24).

\section{SLOTWOORD}

Ek meen ek het nie net die inhoudelike diskontinuïteit ("historiese antitese" - Bultmann 1969b:230) tussen Jesus en die teologie van die kerk aangetoon nie, maar ook die saaklike verband daartussen. Sonder historiese Jesus-navorsing sou hierdie insig nie moontlik gewees het nie. Die geskiedenis van die institusionaliserende kerk wys egter ook daarop dat daar vervreemding van die "waarheid wat in Jesus is", plaasgevind het. Die spore van hierdie institusionalisering is reeds in die Nuwe Testament aanwesig. Alle menslike getuienis (in die norma normans en in die norma normata) behoort altyd krities ondersoek te word of dit in ooreenstemming met hierdie "waarheid" is. Ons bely dat hierdie waarheid in die kanon van die Christendom vervat is (kyk NGB 2-7). Hierdie kritiese ondersoek het ek betrokke hermeneutiek genoem en ek het dit beskryf as die soeke na die waarheid wat in Jesus is - 'n soeke wat nie behoort te eindig nie. Binne die histories-kritiese paradigma noem ons hierdie "soeke" die historiese Jesus-navorsing.

\section{Literatuurverwysings}

Barrett, C K [1957] 1967. A commentary on the epistle to the Romans. Reprinted. London: Adam \& Charles Black. (Black's New Testament Commentaries.) Barth, K [1924] 1933. The resurrection of the dead, tr by H J Stenning. London: SCM. 
Barth, K 1960. Die kirchliche Dogmatik, Vierter Band: Die Lehre von der Versöhnung, Erster Teil. Zürich: EVZ-Verlag.

Bettenson, H 1967. Documents of the Christian church. Second edition. Reprinted. London: Oxford University Press.

Breytenbach, C 1986. Probleme rondom die interpretasie van die "versoeningsuitsprake" by Paulus. HTS 42(4), 696-704.

Bultmann, R [1928] 1969a. The eschatology of the Gospel of John, in Faith and understanding, I, 165-183. Edited-with an introduction by R W Funk, tr by L P Smith. London: SCM.

- [1928] 1969b. The significance of the historical Jesus for the theology of Paul, in Faith and understanding, I, 220-246. Edited with an introduction by R W Funk, tr by $\mathrm{L} P$ Smith. London: SCM.

- [1928] 1969c. Karl Barth, The resurrection of the dead, in Faith and understanding, I, 66-94. Edited with an introduction by R W Funk, tr by L P Smith. London: SCM.

- [1952] 1974. Theology of the New Testament, Volume one, tr by K Grobel. London: SCM.

- [1958] 1968. Theologie des Neuen Testaments. 6., durchgesehene Auflage. Tübingen: Mohr (Paul Siebeck). (Neue Theologische Grundrisse.)

- [1960] 1965. Das Verhaltnis der urchristlichen Christusbotschaft zum historischen Jesus. 4.Auflage. Heidelberg: Carl Winter, Universitätsverlag. (SHAW 3.)

- [1964] [1966] 1971. The Gospel of John: A commentary, tr by G R Beasley-Murray. Oxford: Basil Blackwell.

- 1965. "Antwort an Ernst Käsemann," in Glauben und Verstehen, IV, 190-198. Tübingen: Mohr.

Catchpole, D R 1993. The quest for $Q$. Edinburgh: T \& T Clark.

Capps, D 2000. Jesus: A psychological biography. St Louis, MS: Chalice Press.

Clements, K W 1987. Friedrich Schleiermacher: Pioneer of modern theology. London: Collins. (The Making of Modern Theology.) 
Collins, J J 1984. The apocalyptic imagination: An introduction to the Jewish matrix of Christianity. New York: Crossroad.

Collins, J J 1985. The Testament (Assumption) of Moses, in De Jonge, M J (ed), Outside the Old Testament. London: Cambridge University Press. (Cambridge \& Commentaries on Writings of the Jewish \& Christian Works 200 BC to AD 200,4.)

Crossan, J D 1995. Who killed Jesus: Exposing the roots of anti-Semitism in the gospel story of the death of Jesus. San Francisco: Harper.

- (with R G Watts) 1996. Who is Jesus? Answers to your questions about the historical Jesus. San Francisco: Harper Collins.

- 1998. The birth of Christianity: Discovering what happened in the years immediately after the execution of Jesus. San Francisco, CA: HarperSanFrancisco.

Den Heyer, C J [1996]1996. Opnieuw: Wie is Jezus? Balans van 150 jaar onderzoek naar Jezus. Tweede druk. Meinema: Zoetermeer.

- [1998] 1998. Verzoening: Bijbelse notities bij een omstreden thema. Zevende, uitgebreide druk. Kampen: Kok.

Funk, R W 1994. The resurrection of Jesus: Reports and stories. The Fourth R 7(4), 316.

- 1996. Honest to Jesus: Jesus for a new millennium. San Francisco: Harper Collins. (A Polebridge Press Book.)

- (and The Jesus Seminar) 1998. The acts of Jesus: What did Jesus really do? San Francisco: HarperSanFrancisco. (A Polebridge Book.)

Haitjema, Th L 1962. De Heidelbergse Catechismus als klankbodem en inhoud van het actuele belijden onzer kerk. Wageningen: H Veenman \& Zonen.

Horsley, R A 1987. Jesus and the spiral of violence: Popular Jewish resistance in Roman Palestine. San Francisco: Harper \& Row.

Horsley, R A \& Hanson, J S 1985. Bandits, prophets, and messiahs: Popular movements in the time of Jesus. Minneapolis, MN: Fortress.

Käsemann, E [1954] 1960. "Das Problem des historischen Jesus," in Exegetische Versuche und Besinnungen, Erster Band, 187-214. Göttingen: Vandenhoeck. [Oorspronklik gepubliseer in Zeitschrift fur Theologie und Kirche 51, 125-153.]

- [1973] 1974. An die Römer. 3., überarbeitete Auflage. Tübingen: Mohr. (HNT 8a.) 
Luther, M [1522] WADB 7:382 = [1963] 1990, p. 63. [= "Vorrede auf die Episteln S. Jacobi und Judae," WADB $7=$ Luther Deutsch, Die Werke Luthers in Auswahl, Bd.5.: Die Schriftauslegung, herausgegeben von Kurt Aland].

Malina, B J [1989] 1996. Christ and time: Swiss or Mediterranean?, in Malina, B J, The social world of Jesus and the Gospels, 179-214. London: Routledge.

Martyn, J L 1997. Theological issues in the letters of Paul. Nashville: Abingdon.

Mouton, J \& Pauw, J C 1988. Foundationalism and fundamentalism: A critique, in Mouton, J, Van Aarde, A G \& Vorster, W S (eds), Paradigms and progress in theology, 176-186. Pretoria: HSRC. (HSRC Studies in Research Methodology 5.)

Oetting, W [1964] 1970. The church of the catacombs: An introduction to the surging life of the early church from the apostles to A.D. 250 based on firsthand accounts. Second Printing, Slightly revised. Saint Louis, MS: Concordia Publishing House. (Church in History Series.)

Schleiermacher, F [1830] 1928. The Christian faith, translated of the second edition by $\mathrm{H}$ R Mackintosh \& J S Stewart. Edinburgh: T \& T Clark.

Schlier, H 1957. Der Brief an die Epheser: Ein Kommentar. Düsseldorf: Patmos-Verlag. Schweitzer, A. [1906] 1913. Geschichte der Leben-Jesu-Forschung. Zweite, neu bearbeitete und vermehrte Auflage des Werkes Von Reimarus zu Wrede. Tübingen: Mohr (Paul Siebeck).

Sheehan, T 1995. The resurrection: An obstacle to faith? The Fourth $R$ 8(2), 3-9.

The Fourth $R$ 1995. The Jesus Seminar votes: The resurrection questions. The Fourth $R$ $8(2), 12-17$.

Theissen, G [1999]. Die politische Dimension der Verkündigung Jesu. Voordrag gelewer, Internationales Symposium, Jesus in neuen Kontexten: Sozialwissenschaftlichen Perspektiven der Jesusforschung, Evangelische Akademie Tutzing, 25-27 June 1999.

- [1999] 1999. A theory of primitive Christian religion, tr by J Bowden. London: SCM.

Tracy, D 1981. The analogical imagination: Christian theology and the culture of pluralism. New York: Crossroad: 
Tuckett, CM 1996. $Q$ and the history of early Christianity: Studies on $Q$. Peabody, MS: Hendrickson.

Van Aarde 1999. Dekonstruksie van dogma: 'n Eietydse ondersoek na die spore van die leer van die twee nature van Jesus. HTS 55(2\&3), 437-470.

- 2000a. Jesus als vaterlose Kind: Eine kulturübergreifende und sozialpsychologisches Perspektive, in Stegemann, W (Hrsg), Jesus in neuen Kontexten: Sozialwissenschaftliche Perspektiven der Jesusforschung. Stuttgart: Kohlhammer.

$-2000 \mathrm{~b}$. The continued importance of Jesus. The Fourth $R$ 13(1), 11-16.

- 2000c. Understanding Jesus' healings. Scriptura. (Verskyn later.)

- 2001. Fatherless in Galilee: Jesus child of God. Harrisburg, CA: Trinity Press International.

Van Wyk, D J C 2000. Die relevansie van die historiese Jesus-ondersoek vir kerk en teologie: 'n Hermeneutiese vraagstelling. DD-proefskrif, Fakulteit Teologie, Universiteit van Pretoria.

Van Zyl, F J 1999. Aktualiteit en neerslag van Karl Barth se versoeningsleer in ons teologie, in Van Wyk, D J C (red), 20ste eeu Hervormde teologie, 406-419. Pretoria: Sentik, Ned Herv Kerk.

Wenham, D 1995. Paul: Follower of Jesus or founder of Christianity? Grand Rapids: Eerdmans.

Wilckens, U [1963] 1988. Der Ursprung der Überlieferung der Erscheinungen des Auferstandenen: Zur traditionsgeschichtliche Analyse von 1.Kor. 15, 1-11, in Hoffmann, P (Hrsg) 1988, Zur neutestamentliche Überlieferung von der Auferstehung Jesu, 139-193. Darmstadt: Wissenschaftliche Buchgesellschaft. (WdF 522.)

Wright, N T 1992. Who was Jesus? London/Grand Rapids, MI: SPCK/Eerdmans.

- 1996. Christian origins and the question of God, Vol. 2: Jesus and the victory of God. London: SPCK. 